Disclosure of Interests: Yousra Dakkak: None declared, Debbie Boeters: None declared, Aleid Boer: None declared, Monique Reijnierse Grant/ research support from: Funding from the Dutch Arthritis Foundation. The funding source had no role in the design and conduct of the study., Annette van der Helm - van Mil Grant/research support from: The research leading to these results has received funding from the European Research Council (ERC) under the European Union's Horizon 2020 research and innovation programme (Starting grant, agreement No 714312) and from the Dutch Arthritis Foundation.

The funding source had no role in the design and conduct of the study. DOI: 10.1136/annrheumdis-2019-eular.1698

\section{THU0071 THE COMBINATION OF RHEUMATOID FACTORS WITH ANTIBODY SYSTEMS TARGETING CITRULLINATED, CARBAMYLATED AND PEPTIDYL ARGININE DEIMINASE AUTOANTIGENS DISTINGUISHES RHEUMATOID ARTHRITIS}

Thierry Dervieux ${ }^{1}$, John Conklin ${ }^{1}$, Tyler O'malley ${ }^{1}$, Kelley Brady ${ }^{1}$, Roberta Alexander ${ }^{1}$, Jing Shi ${ }^{1}$, Claudia Ibarra ${ }^{1}$, Michael Mahler ${ }^{2}$, Joel $\mathrm{Kremer}^{3}$, Michael E. Weinblatt ${ }^{4}$, Arthur Weinstein ${ }^{5} .{ }^{1}$ Exagen, Vista, United States of America; ${ }^{2}$ Inova Diagnostics, San Diego, United States of America; ${ }^{3}$ The Center for Rheumatology, Albany, United States of America; ${ }^{4}$ Brigham Women's Hospital, Boston, United States of America; ${ }^{5}$ Georgetown University, Washington D.C., United States of America

Background: Novel antibody systems including anti-Carbamylated Protein Antibody (anti-CarP $\operatorname{lgG}$ ) and anti-Peptidyl Arginine Deiminase Antibody (anti-PAD4 $\operatorname{lgG}$ ) are emerging as independent diagnostic and prognostic biomarkers for Rheumatoid Arthritis (RA) (ref, 1-3). As such, these antibody systems may add value to rheumatoid factor (IgM) and anti-citrullinated peptide antibody (ACPA IgG), the hallmark antibodies in RA.

Objectives: We evaluated the diagnostic performance of Rheumatoid Factor (RF) with antibody systems targeting citrullinated, carbamylated and PAD4 autoantigens in RA.

Methods: The cohort consisted of 638 consenting subjects with RA (fulfilling the 1987 or 2010 ACR classification criteria, mean age: $59.8 \pm 0.5$ years [SEM], $80 \%$ female) and a control group of 775 subjects (mean age: $44.7 \pm 0.5$ years, $85 \%$ females, including Systemic Lupus Erythematosus [ $\mathrm{n}=369]$, primary Sjogren's Syndrome $[\mathrm{n}=64]$, Primary Fibromyalgia [ $n=85$ ], other connective tissue diseases [ $\mathrm{n}=63]$, and a group of normal healthy donors $[n=194])$. Autoantibodies titers from serum were measured using fluoroenzyme immunoassays (anti-RF $[\mathrm{lgM}]$ and anti-CCP [lgG]; Phadia Upsala, Sweden), ELISA (anti-CarP [lgG], research use only [RUO], Inova Diagnostics, San Diego) and bead-based Aptiva ${ }^{\mathrm{TM}}$ technology (anti-PAD4 [lgG], RUO, Inova Diagnostics) in a clinical laboratory accredited by the College of American Pathologists. For each positive antibody (above each cutoff) a score of 1 was assigned and the cumulative presence of the 4 antibodies was determined [range 0-4]. The ability of the biomarkers to distinguish RA from controls was calculated using sensitivity, specificity and interval likelihood ratio (LR). Positive Predictive Value (PPV) was estimated at $10 \%$ pre-test probability. Statistics consisted of Mann-Whitney and Chi-square tests.

Results: In this cohort anti-CarP IgG (>20 Units) yielded $33.5 \%$ sensitivity and $77.9 \%$ specificity. Anti-PAD4 (>1000 Units) yielded $35.0 \%$ sensitivity and $95.0 \%$ specificity. RF IgM ( $>5$ Units $/ \mathrm{ml}$ ) and anti-CCP (>10 Units $/ \mathrm{ml})$ were $67.4 \%$ and $66.5 \%$ sensitive, respectively $(87.5 \%$ and $97.0 \%$ specific, respectively). RA presented 5 -fold higher 4 -antibody system scores (2.02 $\pm 0.05)$ than controls $(0.42 \pm 0.02) ;(p<0.01)$. Scores greater than 2 yielded $42 \%$ sensitivity and $98.8 \%$ specificity. A total of 82 subjects presented with the full-house 4 antibodies (score $=4$ ) while 81 of them had RA (99.9\% specific). Interval LR and PV for each of the 4-antibody score are presented in the Table. There was no difference in the 4-antibody score between RA who fulfilled the 1987 ACR or 2010 ACR criteria $(1.99 \pm 0.07$ vs $2.08 \pm 0.09 ; p=0.40)$. In the subset of subjects newly diagnosed (less than one year), the average 4-antibody system score for RA $(n=33)$ was $1.72 \pm 0.22(36.3 \%$ with score greater than 2$)$ and $0.58 \pm 0.12$ for other diseases $(0 \%$ with score greater than $2, \quad 100 \%$ specific); $(\mathrm{p}<0.01)$.

Conclusion: This cumulative combination of antibody systems targeting citrullinated, carbamylated, PAD4 and Fc autoantigens (RF IgM) is highly specific for RA. It may be useful in diagnosing and classifying RA even in symptomatic patients who present early in the course of disease.

\section{REFERENCES}

[1] Shi, et al. Proc Natl Acad Sci USA. 2011 108(42):17372-7

[2] Darrah E et al. Sci Transl Med. 2013 2;5186ra65

[3] Verheul, et al. Arthritis Rheumatol. 2018 Nov;70(11):1721-1731
Table I: Combination of Rf $\operatorname{lgM}$, anti-CCP (IgG), anti-CarP ( $\lg G)$ and anti-PAD4 $(\operatorname{lgG})$

\begin{tabular}{|c|c|c|c|c|c|c|}
\hline Score & RA $(\%, N)$ & $\begin{array}{l}\text { CTL }(\%, \\
\text { N) }\end{array}$ & $\begin{array}{l}\text { Likelihood } \\
\text { Ratio } \\
\text { [CI 95\%] }\end{array}$ & $\begin{array}{l}\text { Pre-test } \\
\text { Probability }\end{array}$ & $\begin{array}{l}\text { Post-test } \\
\text { Probability }\end{array}$ & Change \\
\hline 0 & $\begin{array}{c}20.5 \% \\
(131 / 638)\end{array}$ & $\begin{array}{c}65.8 \% \\
(510 / 775)\end{array}$ & $\begin{array}{c}0.31[0.27 \text { to } \\
0.37]\end{array}$ & $10 \%$ & $3.4 \%$ & $-6.6 \%$ \\
\hline 1 & $\begin{array}{c}11.6 \%(74 / \\
638)\end{array}$ & $\begin{array}{c}27.2 \% \\
(211 / 775)\end{array}$ & $\begin{array}{c}0.43[0.33 \text { to } \\
0.54]\end{array}$ & $10 \%$ & $4.5 \%$ & $-5.5 \%$ \\
\hline 2 & $\begin{array}{c}25.5 \% \\
(163 / 638)\end{array}$ & $\begin{array}{c}5.8 \%(45 / \\
775)\end{array}$ & $\begin{array}{c}4.40[3.22 \text { to } \\
6.02]\end{array}$ & $10 \%$ & $32.8 \%$ & $22.8 \%$ \\
\hline 3 & $\begin{array}{c}29.6 \% \\
(189 / 638)\end{array}$ & $\begin{array}{c}1.0 \%(8 / \\
775)\end{array}$ & $\begin{array}{c}28.70[14.26 \text { to } \\
57.77]\end{array}$ & $10 \%$ & $76.1 \%$ & $66.1 \%$ \\
\hline 4 & $\begin{array}{c}12.7 \%(81 / \\
638)\end{array}$ & $\begin{array}{c}0.1 \%(1 / \\
775)\end{array}$ & $\begin{array}{c}98.39[13.73 \text { to } \\
705.04]\end{array}$ & $10 \%$ & $91.6 \%$ & $81.6 \%$ \\
\hline
\end{tabular}

Disclosure of Interests: Thierry Dervieux Shareholder of: Exagen (a diagnostics company not a pharmaceutical company), Employee of: Exagen (a diagnostics company not a pharmaceutical company), John Conklin Employee of: Exagen (a diagnostics company not a pharmaceutical company), Tyler O'Malley Employee of: Exagen (a diagnostics company not a pharmaceutical company), Kelley Brady Employee of: Exagen (a diagnostics company not a pharmaceutical company), Roberta Alexander Employee of: Exagen (a diagnostics company not a pharmaceutical company), Jing Shi Employee of: Exagen (a diagnostics company not a pharmaceutical company), Claudia Ibarra Shareholder of: Exagen (a diagnostics company not a pharmaceutical company), Employee of: Exagen (a diagnostics company not a pharmaceutical company), Michael Mahler Employee of: Inova Diagnostics (Not pharmaceutical, diagnostics company), Joel Kremer Shareholder of: Corrona, Consultant for: AbbVie, Amgen, Bristol-Myers Squibb, Genentech, GSK, Lilly, Pfizer, Regeneron and Sanofi, Employee of: Corrona, Michael E. Weinblatt Shareholder of: Stock option: CanFite, Lycera, Scipher, Inmedix, Grant/research support from: Crescendo Bioscience, Bristol Myers Squibb, Sanofi, Consultant for: AbbVie, Amgen, Bristol-Myers Squibb, CanFite, Corrona, Crescendo, GlaxoSmithKline, Gilead, Horizon, Lilly, Lycera, Merck, Novartis, Pfizer, Roche Samsung, Scipher, Set Point, Arthur Weinstein Shareholder of: Exagen (a diagnostics company not a pharmaceutical company), Consultant for: Exagen (a diagnostics company not a pharmaceutical company) DOI: 10.1136/annrheumdis-2019-eular.6351

\section{THU0072 ULTRASOUND PREDICTS IMMINENT PROGRESSION TO ARTHRITIS IN ANTI-CCP POSITIVE AT-RISK INDIVIDUALS}

Laurence Duquenne $^{1,2}$, Kulveer Mankia $^{1,2}$, Jacqueline Nam ${ }^{1,2}$, Peta Pentony ${ }^{1,2}$, Leticia Garcia-Montoya ${ }^{1,2}$, Andrea Dimatteo $^{1,2}$, Laura Hunt ${ }^{1,2}$, Paul Emery ${ }^{1,2}$.

${ }^{1}$ Leeds Institute of Rheumatic and Musculoskeletal Medicine, Leeds, United Kingdom; ${ }^{2}$ NIHR Leeds Biomedical Research Centre, Leeds, United Kingdom

Background: Ultrasound (US) Power Doppler (PD) signal is predictive for the development of inflammatory arthritis (IA) in anti-cyclic citrullinated protein antibodies positive (CCP+) individuals with musculoskeletal (MSK) symptoms but no clinical synovitis (CS) [1]. Our previous data showed a late increase in the overall US inflammation before arthritis development, suggesting that a sub-clinical phase of synovitis could be detected [2] This abstract describes the prediction of PD abnormalities in the months following US scan.

Objectives: 1 . Presence of PD in one joint is predictive of imminent progression to $I A$ in the next 3months.

2. A rise in the number of joints with presence of $P D$ increases the odds of progression to IA.

Methods: In a single-centre prospective observational cohort between June 2008 and December 2018, 307 CCP+ patients with a new MSK symptom but no synovitis were followed until CS occurred. Clinical and US findings were analysed. Following our previous study, we compared progression in the 3,12 or $>12$ months after a US scan. 38 joints were included in the analysis (MTPs, hands, wrists, elbows, ankles and knees). Patients with palindromic rheumatism were excluded.

Results: Data from $96 \mathrm{CCP}+$ at-risk patients who developed CS (progres sors) are compared to $211 \mathrm{CCP}+$ patients who did not (non-progressors) Age and gender are similar, the mean follow-up of the non-progressors is higher, with significantly more smokers and high titre CCP in the progressors group (Table1).

Overall, progressors have more joints with PD than non-progressors (Figure1). Patients with PD in one joint are more likely to develop CS in the following 3 months compared to those without PD (OR 7.52) and this remain significant when only the hands and wrists are included 
(Table2). The highest $\mathrm{OR}$ is shown when $\mathrm{PD} \geq 2$ is found in at least one wrist. Similarly, there is a significant but smaller prediction of progression between 3 to 12 months after US (Table2).

When a new joint develops PD, the likelihood of progression to IA within the next 3 months increases (Table2). This is especially predictive with wrists involvement (OR 3.10). Prediction of progression between 3 to 12 months before CS is significantly different between groups, with a higher OR for the wrists.

Conclusion: The presence of PD in one joint and every new joint with PD are both predictive of progression to IA within the next 3months. These results should lead to a logical programme for therapy and follow -up.

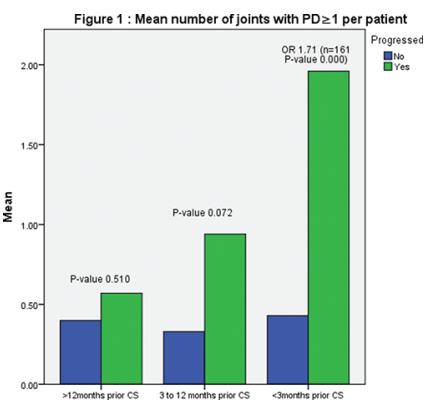

Abstract THU0072- Figure 1

\section{REFERENCES:}

[1] Nam J. et al., US findings predict progression to inflammatory arthritis in anti-CCP positive patients without CS. Ann Rheum Dis, 2016. 75(12).

[2] Pentony $\mathrm{P}$, et al., Sequential US shows a late increase in inflammatory burden in anti-ccp positive patients with non-specific MSK symptoms just before progression to IA. Ann Rheum Dis, volume 77, year 2018

Table 1. demographics

\begin{tabular}{lccc}
\hline & Progressors & $\begin{array}{c}\text { Non- } \\
\text { progressors }\end{array}$ & $\begin{array}{c}\mathrm{p}- \\
\text { value }\end{array}$ \\
\hline $\mathrm{N}$ & 96 & 211 & \\
Age $^{*}$ & $53.4(13)$ & $49.8(13.2)$ & 0.494 \\
CCP titre: High/Low(\%) & $92.7 / 7.3$ & $50.2 / 48.8$ & 0.000 \\
Gender F/M(\%) & $74 / 26$ & $74.9 / 25.1$ & 0.863 \\
Weeks follow-up* & $76.44(93.5)$ & $189.9(126.5)$ & 0.000 \\
Smoker: Ever/Never & $72.9 / 27.1$ & $48.3 / 51.7$ & 0.000 \\
$(\%)$ & & & \\
\hline${ }^{*}$ Mean(SD) & & &
\end{tabular}

Table 2. Probability of progression

\begin{tabular}{|c|c|c|c|c|c|c|c|c|c|}
\hline \multicolumn{10}{|c|}{ if $P D \geq 1$ in $\geq 1$ joint } \\
\hline & \multicolumn{3}{|c|}{$<3 \mathrm{M}$} & \multicolumn{3}{|c|}{ 3-12M } & \multicolumn{3}{|c|}{$>12 \mathrm{M}$} \\
\hline & OR (Cl) & $\begin{array}{c}\mathrm{P} \text { - } \\
\text { value }\end{array}$ & $\mathbf{n}$ & OR & $\begin{array}{c}\mathrm{P}- \\
\text { value }\end{array}$ & $\mathbf{n}$ & OR & $\begin{array}{c}\mathrm{P}- \\
\text { value }\end{array}$ & n \\
\hline $\begin{array}{l}\text { All } \\
\text { joints }\end{array}$ & $\begin{array}{c}7.52 \\
(2.9,18.9)\end{array}$ & 0.000 & 161 & 3.17 & 0.006 & 174 & & 0.177 & 125 \\
\hline Hands & $\begin{array}{c}5.01 \\
(2.1,11.9)\end{array}$ & 0.000 & 187 & 3.39 & 0.004 & 219 & & 0.174 & 148 \\
\hline Wrists & $\begin{array}{c}4.47 \\
(1.9,10.5)\end{array}$ & 0.001 & 188 & 5.21 & 0.000 & 219 & & 0.999 & 148 \\
\hline \multicolumn{10}{|c|}{ for every new joint with $P D \geq 1$} \\
\hline & & & & & $3-12 M$ & & & $>12 \mathrm{M}$ & \\
\hline $\begin{array}{l}\text { All } \\
\text { joints }\end{array}$ & $1.71(1.3,2.3)$ & 0.000 & 161 & 1.38 & 0.020 & 174 & & 0.678 & 125 \\
\hline Hands & $1.83(1.2,2.7)$ & 0.003 & 187 & 1.72 & 0.013 & 219 & & 0.301 & 148 \\
\hline Wrists & $3.10(1.6,5.8)$ & 0.000 & 188 & 3.05 & 0.000 & 219 & & 0.998 & 148 \\
\hline \multicolumn{10}{|c|}{ if $P D \geq 2$ in $\geq 1$ joint } \\
\hline & & & & & $3-12 M$ & & & $>12 \mathrm{M}$ & \\
\hline $\begin{array}{l}\text { All } \\
\text { joints }\end{array}$ & $2.63(1.5,4.5)$ & 0.001 & 161 & 2.29 & 0.012 & 174 & & 0.128 & 125 \\
\hline Hands & $2.89(1.4,5.9)$ & 0.004 & 187 & & 0.137 & 219 & & 0.078 & 148 \\
\hline Wrists & $\begin{array}{c}12.11 \\
(3.2,46.5)\end{array}$ & 0.000 & 188 & 5.78 & 0.015 & 219 & & 0.999 & 148 \\
\hline
\end{tabular}

Disclosure of Interests: Laurence Duquenne: None declared, Kulveer Mankia Grant/research support from: Research support from BMS and Lilly, Speakers bureau: Honoraria from Abbvie, UCB, Jacqueline Nam: None declared, Peta Pentony: None declared, Leticia Garcia-Montoya:
None declared, Andrea DiMatteo: None declared, Laura Hunt: None declared, Paul Emery Grant/research support from: Pfizer, MSD, AbbVie, Bristol-Myers Squibb, Roche, Consultant for: Pfizer, MSD, AbbVie, BristolMyers Squibb, UCB, Roche, Novartis, Gilead,Samsung, Sandoz and Lilly DOI: 10.1136/annrheumdis-2019-eular.7860

\section{THU0073 HAVE THE CLINICAL CHARACTERISTICS OF RHEUMATOID ARTHRITIS AT PRESENTATION BECOME MILDER OVER TIME? RESULTS FROM A NATIONWIDE STUDY OVER THREE DECADES IN SWEDEN}

Jon Einarsson, Tor Olofsson, Olafur Palsson, Johan K Wallman, Meliha C Kapetanovic. Lund University, Department of Clinical Sciences Lund, Section of Rheumatology, Lund, Sweden

Background: The course of rheumatoid arthritis (RA) has become milder during the last decades, which could at least partly be attributed to major advances in the pharmacological treatment of the disease and the implementation of "treat to target"-strategies $(1,2)$. It has also been suggested that RA is already milder at presentation (3)

Objectives: To investigate whether the clinical status, markers of inflam mation, functional status, and patient and evaluator reported disease activity measures in patients with newly diagnosed RA, have improved over the recent decades.

Methods: Baseline data on all DMARD-naïve patients with early RA $(<6$ months duration) included in the nationwide Swedish Rheumatology Quality registry (SRQ) between 1991 and 2014 were retrieved. The RA diagnosis relied on the clinical judgement of the treating physician and the information comprised swollen and tender joints count (SJC; TJC) markers of inflammation (CRP; ESR), functional status (HAQ; 0-3), patient's and evaluator's assessment of global disease activity (PtGA EGA) and patient's assessment of pain (on a visual analog scale, VAS; 0-100 mm). Baseline demographic and disease characteristics were com pared between patients with disease onset 1991-2000 vs. those with onset 2011-2014, using Mann-Whitney $U$ test and Pearson's chi-squared test.

Results: A total of 6559 early RA patients were included. Over the study period of 23 years the majority of the patients were women $(68 \%)$, and the mean age at inclusion increased from 57,4 to 59,1 years. Results are summarised in Table 1. Mean CRP, ESR, TJC and SJC all decreased significantly between the two time periods compared, which was also the case for HAQ. In contrast, mean pain, PtGA and EGA increased significantly between the time periods. Furthermore, time from symptom onset to inclusion was shorter 2011-2014.

\begin{tabular}{lcccc}
\hline TABLE 1 (Mean (SD)) & $\mathbf{1 9 9 0 s}$ & $\mathbf{2 0 0 0 s}$ & $\mathbf{2 0 1 1 - 2 0 1 4}$ & p-value $^{*}$ \\
Number of patients & 1227 & 4344 & 988 & - \\
Age at inclusion (years) & $57,4(15,4)$ & $58,4(15,0)$ & $59,1(14,7)$ & 0,006 \\
Female gender & $67,3 \%$ & $67,6 \%$ & $70,4 \%$ & 0,12 \\
Time from symptom onset (months) & $3,8(1,5)$ & $3,6(1,5)$ & $3,3(1,5)$ & $<0,001$ \\
CRP (mg/L) & $33,1(36,3)$ & $29,3(36,7)$ & $22,6(29,9)$ & $<0,001$ \\
ESR (mm) & $36,4(25,8)$ & $35,4(24,8)$ & $32,4(23,7)$ & $<0,001$ \\
TJC (0-28) & $8,0(6,6)$ & $8,0(6,1)$ & $7,1(6,0)$ & 0,005 \\
SJC (0-28) & $9,5(5,9)$ & $9,0(5,8)$ & $7,6(5,5)$ & $<0,001$ \\
HAQ (0-3) & $1,1(0,6)$ & $1,1(0,6)$ & $1,0(0,6)$ & 0,028 \\
EGA(VAS 0-100) & $50,3(19,5)$ & $54,4(19,4)$ & $54,8(20,1)$ & $<0,001$ \\
Pain (VAS 0-100) & $49,5(26,1)$ & $52,3(25,5)$ & $53,4(26,4)$ & $<0,001$ \\
PtGA (VAS 0-100) & $48,6(26,7)$ & $52,4(25,5)$ & $51,8(26,7)$ & 0,006 \\
\hline
\end{tabular}

\section{*1990S vs 2011-2014}

Conclusion: In Swedish patients with early RA, baseline joint counts and inflammatory markers improved over the last three decades. This could partly be explained by shorter symptom duration at diagnosis but also suggests that, at onset, RA might be an inherently milder disease today. However, pain and patient's global assessment and evaluator's global assessment of disease activity increased over the same period of time, possibly indicating changes in both patients' and evaluators' expectations for management of early RA today

REFERENCES:

[1] Gwinnutt, et al. Arthritis Rheumatol. 2017; 69:1566-75.

[2] Matsumoto, et al. J Rheumatol. 2017; 44:1575-82.

[3] Diffin, et al. J Rheumatol. 2014; 41:1590-9. 